\title{
The Communication Behaviour of Deaf Children in SLB Negeri 1 Tabanan: Ethnographic Communication Perspective
}

\author{
I Wayan Wirta ${ }^{1}$, Ida Bagus Putu Supriadi ${ }^{1}$, Ida Ayu Kartika Maharani ${ }^{1 \star}$ \\ ${ }^{1}$ Universitas Hindu Negeri I Gusti Bagus Sugriwa, Denpasar, Indonesia
}

\begin{abstract}
The aim of the research is to identify and interpret field data on subcultures, total communication approaches, communication components forming communication events, patterns and communication skills of deaf children at the research site. Three important things have been identified in this research. First the subculture and overall communication approach of deaf children has been identified as a typical culture of deaf children in SLB Negeri 1 Tabanan. Second, the dominant communication components shaping the communication events of deaf children in SLB Negeri 1 Tabanan are (1) Settings, including the ideal distance to communicate, physical asp. The three patterns and communication skills of deaf children in SLB Negeri Tabanan identified were (1) patterns of communication between deaf children and normal people and (2) patterns of communication between deaf children and deaf children. The patterns of communication with normal people are divided into patterns of communication with older people and patterns of communication with peers.
\end{abstract}

Keywords: Communication behavior, deaf children, special need schools, communication ethnography

\section{Research Background}

The results of the Inter-Census Population Survey (SUPAS) in 2015, showed that the number of people with disabilities in Indonesia reached 21.84 million people or $8.56 \%$ of Indonesia's population. In particular regarding data on people with hearing disabilities, according to the World Health Organization (WHO), in 2019 it is estimated that there are 466 million people in the world or around 5.3\% or as many as 360 million people in the world who experience hearing loss. Of that number, 34 million of them are children (Indonesia Kemenkes RI, 2012).

Data from one of the studies states that $35 \%$ of the total number of Indonesian children are children with low language skills due to hearing impairments or deafness. (Kuswarno, 2009). This low ability does not come from his low intellectual ability, but because his intelligence does not have the opportunity to develop (Salim, 1984). The problem of deaf children in special schools is very interesting to study because they are 
assumed to have low abilities in the language field. There is an assumption that the low level of language acquisition among children with hearing impairment is the result of this disability (Brenneis, 2020). They need proper education and guidance from their environment, so that their intellectual development and social life are not hampered. This means that a special school for deaf children is needed (Salim, 1984). In Indonesia, such schools are called Special Schools Part B. Schools for deaf children play a very important role (Anshori, 2017).

Schools are not only agents of the first socialization of Indonesian sign language, but also as agents for shaping knowledge and language skills for deaf children (Salim, 1984). For deaf children, it is in this school that an understanding of reality and language skills is obtained (Kuswarno, 2009).

Deaf children at the Tabanan Special State School 1 were the object of ethnographic communication research at the micro-level. This is in accordance with the opinion (Kuswarno, 2009) that the deaf lacks or is unfamiliar with the structures or patterns of spoken language, which require a lot of listening skills. Often times they know the word but don't know its meaning, or vice versa, they know the object but don't know the name. For that, it is also a natural need for children with hearing impairment to have their own linguistic system.

Based on the background of the problems above, the following problems can be formulated: (1) "What is the subculture and total communication approach, deaf children in SLB Negeri 1 Tabanan?". (2) "What components of communication shape the communication incidents of deaf children in SLB Negeri 1 Tabanan?" (3) "What is the pattern and communication competence of deaf children in SLB Negeri 1 Tabanan?".

The results of this study are expected to be useful as study material that can be published in scientific journals. Thus, it can serve as a contribution of thought to the development of communication science, especially the development of theories related to research on group communication behavior in society, especially those related to the communication process using non-vocal verbal language.

At the same time, it is also hoped that it can be used as input for those who are interested in or are involved with deaf children, to further encourage effective communication in the environment of children with hearing impairment. More specifically, through this research, it is hoped that communication lines will be opened up for both people who are deaf and between deaf and non-deaf (normal). This increases the opportunity for those who are deaf to communicate with others, as well as making it easier for normal people to communicate with them. 


\section{Research Theory}

Theory contributes to the study in terms of increasing the success of the analysis and providing explanations for the relationships observed in a study. This research used (1) Symbolic Interaction Theory, (2) Ethnomethodology Theory (3) Social Reality Construction Theory. These three theories are expected to provide direction to describe and interpret the data that has been collected in the field.

Symbolic interaction theory was introduced by Herbert Blumer, although it was previously initiated by George Herbert Mead. Blumer succeeded in modifying Mead's theory for specific purposes. The basic characteristic of this theory is the interaction and communication between humans as individuals in a society (Sukidin, 2002). This theory is based on three basic assumptions, namely: (1) humans act on something based on the meanings that exist in that something for them; (2) the meaning is obtained from the results of social interactions carried out by others, and (3) these meanings are perfected when the social interaction process is taking place. (Sukidin, 2002). With the theoretical assumptions mentioned above, it can be used to discuss the communication behavior of deaf children in SLB Negeri 1 Tabanan, eclectically along with other theories. It is expected to be able to find specific facts related to (1) sign language activities of deaf children where the elements of written culture are more dominant; (2) the meaning of sign language symbols that are exchanged in the social interaction of deaf people; (3) the meaning of sign language symbols develops, changes, and is perfected in the process of social interaction.

The ethnomethodology theory was developed by Harold Garfinkel, as a branch of sociology. One of Garfinkel's key positions regarding ethnomethodology is that actors of communication can be explained reflectively (Ritzer, 2005). There are several types of ethnomethodological work, including the study of institutional settings and conversational analysis. In this study, conversation analysis seems to be more relevant. The purpose of conversation analysis is to understand in detail the fundamental structure of conversational interactions (Zimmerman \& Martinez-Pons, 1988)

Conversation analysis is based on the assumption that: (1) conversation is the basis of the forms of relationship between other personal; (2) conversation is the most pervasive form of interaction; (3) the conversation consists of the most organized matrix of communication procedures and practices. This theory will be used eclectically with symbolic interaction theory, and social reality construction theory, to identify and interpret data about the communication behavior of deaf children in SLB Negeri 1 Tabanan.

The theory of social reality construction was proposed by Alfred Schultz through the concept of phenomenology, which was later developed in the book "The Social Constructure of Reality" by Peter Berger and Thomas Luckman. With support from Schultz's flow of symbolic interaction and phenomenalism, Berger argues that social 
construction of reality focuses attention on the process by which individuals respond to events around them based on their experiences. (Berger, 1990)

The assumptions that underlie the construction of social reality (Sendjaja et al., 2014) are: (1) Social reality does not exist by itself, but is known and understood through experiences influenced by language; (2) Social reality is understood through language that grows from social interaction at a certain time and place; (3) Social reality is understood to depend on existing social conventions; (4) An understanding of social reality that is socially structured forms many important aspects of life, such as thinking and behavior activities.

\section{Method}

This research is categorized into qualitative, not quantitative, research (Pujileksono, 2015). The approach used is the ethnographic approach to communication (Kuswarno, 2009), because to discuss the typical communication behavior of deaf children requires an understanding of the workings of the elements of language, communication, and culture at the same time, which is almost impossible to rely on quantitative research. (Ibrahim, 1994). Because the thing that is wanted to be discovered and studied further in this study is the communication behavior of deaf children in SLB Negeri 1 Tabanan, it is appropriate that ethnography of communication be used as a typical research approach. (Ibrahim, 1994).

However, due to time constraints, the communication ethnography research was carried out only micro communication ethnography or small communication ethnography (Sukidin, 2002). The ethnographic study of micro communication in this research is limited to three elements that shape communication behavior, namely: First, about the subculture and total communication approach in SLB Negeri 1 Tabanan; Second, regarding the communication components that shape the communication events of deaf children at SLB Negeri Tabanan; Third, about communication patterns and competencies in SLB Negeri 1 Tabanan.

The research location was chosen in the State Special School (SLB) 1 Tabanan. The type of data collected is qualitative data, including primary data and secondary data. Determination of key informants tends to use purposive sampling technique (Mulyana, 2006). The data collection techniques used were focused observation, in-depth interviews, document study and literature study. The research data analysis was carried out based on the assumptions of symbolic interaction theory, ethnomethodology, and eclectic social reality construction. In this study, data validity testing techniques were used, namely participation extension, observation persistence, and triangulation (Moleong, 2014).

\section{Results}

\subsection{Deaf Subculture and Total Communication Approach in SLBN 1 Tabanan}


Two important points have been identified for the deaf subculture and the total communication approach, namely (1) the deaf subculture which includes: (a) the sign language used; (b) espoused values; (c) preferred behavior; (d) aspirations related to the use of technology / materials; (e) pride in history / historical places for the deaf; (f) interest / involvement in arts and humor; (2) total communication approach for children with hearing impairment which includes: (a) a philosophical approach; (b) main benefits; (c) the form of total communication education focus expression; (d) Oral and manual are two important factors of total communication; (e) total communication role; (f) implementation of total communication education. These two points will be analyzed and discussed based on symbolic interaction theory, ethnomethodology, and the construction of social reality in an eclectic manner.

The deaf subculture and the total communication approach according to the view of symbolic interaction are: (1) sign language activity is the dominant element in the deaf subculture; (2) the meaning of the sign language symbols is always exchanged in every social interaction of children with hearing impairment; (3) the meaning of sign language symbols develops, changes and is perfected in the process of social interaction; (4) being deaf is natural, it is part of their daily life. Normal people are seen as showing less acceptance of themselves if they want to express sadness or regret for their deafness.

Likewise, the deaf subculture and the total communication approach according to the view of social reality construction are: (1) the experience of deaf children in sign language is a social reality that exists and occurs factually; (2) the interaction of children with hearing impairment has occurred in the past and is currently happening in SLB Negeri 1 Tabanan; (3) children with hearing impairment use sign language in social interactions, which depend on the existing social conventions in SLB Negeri 1 Tabanan; (4) Deaf children's understanding of the way they communicate which shapes the activities of thinking and behaving in their daily lives.

Based on the analysis and discussion above, it can be stated that the language used to communicate at school and at home by deaf children forms their distinctive subculture, and forms their identity as a deaf community in SLBN 1 Tabanan.

\subsection{Communication Component for Deaf Children in SLBN 1 Tabanan}

The components of communication for deaf children in SLB Negeri 1 Tabanan identified in the field are: (1) Deaf children use several communication aids; (2) The communication process takes place according to certain communication situations; (3) There are several communication components that play a major role in shaping communication events for children with hearing impairment; (4) It is also known that several communication components have played a less role in shaping the communication events of deaf children. The four points can be explained in terms of symbolic interactions, ethnomethodology, and social reality construction. 
Symbolic interaction views that the communication component of deaf children in SLBN 1 Tabanan has its own meaning in every communication event. These meanings are always communicated through messages in daily life or through social interactions. In the course of time the understanding of these meanings can change, develop, and experience perfection in the process of social interaction.

Ethnomethodology views that the communication component of deaf children in SLBN 1 Tabanan is that: (1) the realization of a communication process (conversation) with other people, both with normal and deaf people, especially to facilitate interpersonal communication and to strengthen social interactions; (2) facilitate or permeate the communication process (conversation) through social interaction; (3) adhere to organized communication practice procedures.

Social reality construction views the communication component of deaf children in SLBN 1 Tabanan that (1) the social reality of communication events for deaf children can be understood through: the communication situation that occurs, the tools used, the settings, participants, message forms, interaction rules, and the existence of several communication components that do not play a role in the formation of communication events.

Based on the analysis and discussion above, it can be stated that the communication components of deaf children in SLBN 1 Tabanan include (1) several communication aids by deaf children; (2) communication that takes place in accordance with certain communication situations; (3) identification of several communication components that have the most role in shaping communication events for children with hearing impairment; (4) and also identified several communication components that did not play a role in shaping communication events for deaf children.

\subsection{Communication Patterns and Competencies of Deaf Children}

The communication patterns and competences of deaf children in SLB Negeri 1 Tabanan, which are identified are two important points, namely: (1) There is a communication pattern for deaf children, which consists of (a) the pattern of communication between children with hearing and normal people and (b) communication patterns. deaf children with other deaf people; (2) The communication competence of children with hearing impairment, which includes: (a) linguistic skills and (b) interaction skills. The communication patterns and competencies of deaf children in SLBN 1 Tabanan according to the view of symbolic interaction, ethnomethodology, and social reality construction, can be described as follows.

Symbolic interactions looked at the communication patterns and competences of deaf children in SLBN 1 Tabanan that: (1) Every communication pattern and competence of deaf children in a communication event had an important meaning for children with hearing impairment. The meanings are the same and there are different in 
every communication event that occurs in daily life or through social interactions. Gradually the understanding of the meanings of communication patterns and competencies can change, develop, and experience improvements in the process of social interaction.

Ethnomethodology views the communication patterns and competences of deaf children in SLBN 1 Tabanan that (1) the communication patterns and competences of deaf children occur because of the communication process (conversation) that strengthens interpersonal relationships between individuals; (2) communication patterns and competencies occur because of the ease or permeability of the communication process; (3) communication patterns and competencies can be realized because there is an effort to comply with organized communication practice procedures.

The social reality construction sees the communication patterns and competences of deaf children in SLBN 1 Tabanan that (1) the social reality of communication patterns and competences of deaf children can be understood through the experience of communicating with sign language; (2) this social reality is experienced through social interactions at certain times at school and at home; (3) that social reality is experienced depending on existing social conventions; (4) the social reality that underlies the thinking activities of the deaf child. Based on the analysis and discussion above, it can be stated that the communication patterns and competences of deaf children in SLBN 1 Tabanan are formed from speech acts / communicative actions that are influenced by elements of language use (linguistics), social interaction, and deaf culture itself.

\section{Conclusion}

The following conclusions can be drawn. (1) There is a close relationship between the use of two communication channels, namely oral and manual communication channels, which occur simultaneously with the occurrence of special communication events. If there is a change in the channel used, it will result in a significant change in communication events. The main indicator of a communication channel as a marker of a communication event is the change in communication components that make up a communication event; (2) Deaf children tend to use spoken language when communicating with normal people, and conversely tend to use sign language when communicating with other deaf people. So, there are two communication events that are typical for the behavior of deaf children, namely communication events with normal people and communication events with deaf people. These two events become special events that indicate the uniqueness of the communication behavior of deaf children, because both of them underlie their overall communication behavior; (3) The communication component of deaf children does not entirely play a role in shaping communication events. Among the ten components of communication, message form, interaction rules and interaction norms can change according to the participant and the setting in which the event occurs. On the other 
hand, topic, type of communication event or genre as well as purpose of communication, sequence of actions and message content, do not appear to have a major role in shaping communication events. This is seen in the absence of major differences in the two communication events; (4) Communication patterns and competencies can be seen from the relationships between components, which can be identified, namely the communication patterns of deaf children with normal people and communication patterns of deaf children with deaf people. From the two, it was also identified that each of them had a variant of communication patterns with older people and communication patterns with younger people or the same age.

This study is a micro-scale ethnographic communication study; therefore the findings are predicted to only apply to the deaf population in SLB Negeri 1 Tabanan. In addition, the focus of the research is only around communication behavior with a deaf cultural variant, and the total communication approach, communication components, patterns and communication competencies which are discussed from the ethnographic point of view of communication. So the results of this study have not been able to describe the communication behavior of deaf children holistically. For this reason, further research is suggested to: (1) conduct a more detailed and detailed research on deaf culture for the deaf community in the wider society; (2) conduct further research on communication behavior with other material objects, apart from the communication behavior of children with hearing impairment; (3) conduct further research on the components, patterns and communication competencies of deaf children in other perspectives.

\section{References}

Anshori, D. S. (2017). Etnografi Komunikasi: Perspektif Bahasa. Jakarta: Raja Grafindo Persada.

Berger, P. L. (1990). Tafsir Sosial Atas Kenyataan. Jakarta: Lembaga penelitian, pendidikan, dan penerangan ekonomi dan sosial. Lembaga Penelitian, Pendidikan, dan Penerangan Ekonomi dan Sosial.

Brenneis, D. (2020). No Title. Language in Society, 16(1), 111-113. http://www.jstor.org/stable/4167818

Ibrahim, A. S. (1994). Panduan penelitian etnografi komunikasi. Surabaya: Usaha Nasional.

Indonesia Kemenkes RI. (2012). Buletin Jendela Data Dan Informasi Kesehatan Semester 1.

Kuswarno, E. (2009). Fenomenologi: metode penelitian komunikasi: konsepsi, pedoman, dan contoh penelitiannya. Widya Padjadjaran.

Moleong, L. J. (2014). Metodologi Penelitian Kualitatif (Edisi Revi). PT Remaja Rosdakarya.

Mulyana, D. (2006). Metodologi penelitian kualitatif: paradigma baru ilmu komunikasi dan ilmu sosial lainnya. PT Remaja Rosdakarya. 
Pujileksono, S. (2015). Pengantar Anropologi Memahami Realitas Sosial Budaya. Intrans Publishing.

Ritzer, G. (2005). Teori sosiologi modern. Prenada Media.

Salim, M. (1984). Pendidikan Anak Tunarungu (Proyek Pen). Departemen Pendidikan dan Kebudayaan.

Sendjaja, S. D., Rahardjo, T., Pradekso, T., \& Sunarwinadi, I. R. (2014). Teori Komunikasi. In: Memahami Teori Komunikasi: Pendekatan, Pengertian, Kerangka Analis, dan Perspektif. Universitas Terbuka.

Sukidin, B. (2002). Metode Penelitian Kualitatif Perspektif Mikro. Surabaya: Insan Cendekia.

Zimmerman, B. J., \& Martinez-Pons, M. (1988). Construct validation of a strategy model of student self-regulated learning. Journal of Educational Psychology, 80(3), 284290. https://doi.org/10.1037/0022-0663.80.3.284 